\title{
EDITORIAL
}

\section{ANATOMÍA HUMANA: CIENCIA, ÉTICA, DESARROLLO Y EDUCACIÓN}

\author{
Roberto Javier Rueda Esteban', Juan David Hernández Restrepó \\ ${ }^{1}$ Médico, Universidad de los Andes; Grupo de Investigación en Anatomía para la Educación. \\ ${ }^{2}$ Profesor asociado anatomía y cirugía, Universidad de los Andes y Hospital Universitario Fundación Santafé de Bogotá. \\ Grupo de Investigación en Anatomía para la Educación.
}

Recibido: Septiembre 1 de 2012

El estudio de la anatomía ha permanecido por siglos como una ciencia neutral en el ámbito ético, considerando la buena disección y disposición de los especímenes como su base fundamental. Esta imagen se ha mantenido desde los inicios de su estudio y desarrollo con el descubrimiento del formaldehido, el cual permitió prolongar el tiempo de disección antes limitado por el proceso natural de la putrefacción, hasta la actualidad en que se utilizan polímeros, preparaciones especiales y exposiciones no convencionales tanto en su enseñanza como en su investigación.

La actual crisis que se ha descrito en el proceso enseñanza-aprendizaje de la anatomía ha generado dos corrientes educativas utilizadas ampliamente alrededor del globo, una basada aún en la disección cadavérica la cual se considera una actividad vital, la segunda utilizando principalmente la amplia gama de herramientas que el avance de la tecnología ha permitido desarrollar. Sin embargo, estas corrientes no se utilizan de manera excluyente, y es común observar que la educación anatómica utilice una mezcla de estas dos prácticas para llevar a cabo la tarea de enseñar no sólo los aspectos anatómicos descriptivos, sino la noble labor de inculcar en el futuro profesional médico valores éticos con respecto al cuerpo humano y la praxis médica.

Hay innumerables casos de utilización anti-ética del cuerpo humano durante el tiempo que se ha llevado a cabo el estudio anatómico, cuyos resultados no deben
Aceptado: Noviembre 6 de 2012

necesariamente ser satanizados ni censurados, ya que incluso bajo presiones políticas erróneas, el estudio de la anatomía y la utilización del llamado "atlas" humano es un tributo a quienes han fallecido. Más bien deben ser analizados, para que sean una herramienta valiosa en la formación ética, médica e histórica del futuro profesional médico.

En la actualidad, en pocos países se han planteado las consideraciones éticas y legales bajo las cuales debe regirse el estudio del cuerpo humano. Colombia es una de las excepciones, ya que tan sólo se encuentran reglamentados algunos apartes dentro de la amplia gama de labores que acarrea el estudio del cuerpo humano por parte del Instituto Nacional de Medicina Legal y Ciencias Forenses (INML), todo lo demás se rige casi exclusivamente por la premisa del respeto al cadáver humano. Al parecer, las leyes rigen más firmemente problemas como el diagnóstico, tratamiento y rehabilitación de la enfermedad de lo que deberían hacerlo en un terreno de tanta delicadeza como lo es la utilización de cadáveres en educación.

Es importante entonces, que en un ámbito libre, tanto dentro como fuera del anfiteatro, el futuro profesional médico sea entrenado por los anatomistas en un terreno tan delicado como lo es la ética médica. Y es labor primordial del investigador, disector o profesor inculcar la ética y el respeto dentro de las actividades formativas médicas, como competencias fundamentales en la práctica médica.

* Grupo de Investigación en Anatomía para la Educación, Facultad de Medicina, Universidad de los Andes, Bogotá D.C. Colombia. Correo Electrónico: rj.ruedae@gmail.com, Teléfono: 057(1) 5101917; Móvil: 315-6703601 Dirección: Calle 120 No 70C - 33, Barrio Niza Antigua, Bogotá D.C. Colombia 
Considerada por siglos una de las piedras angulares de la educación médica e históricamente cuna de múltiples dilemas éticos y religiosos, debido a la utilización de cadáveres o atlas anatómicos para su estudio, la anatomía ha recorrido un largo camino bajo la imagen de un territorio éticamente neutral, basado esto en la forma en que se conservan y presentan los restos humanos (2) y dedicada al estudio descriptivo de la anatomía macroscópica. Una imagen probablemente errónea que hoy en día ha intentado ser desechada (1). Desde el descubrimiento del formaldehido en el siglo XIX, el estudio de la anatomía pudo prolongarse durante el tiempo que el espécimen soportara la disección, y la limitante de tiempo determinada por el proceso natural de la putrefacción dejo de ser un problema. Desde entonces, se dio inicio a una carrera en busca de nuevas y mejores técnicas de preservación en pro de la enseñanza, el estudio de la anatomía y la libertad para ejercerla, dejando de lado muchas veces las consideraciones éticas que la utilización de dichas técnicas podría acarrear.

De acuerdo con estos desarrollos y probablemente con que la enseñanza y aprendizaje de anatomía se encuentra en crisis $(3,4,5)$, se plantearon dos tendencias para enseñar anatomía. La primera, insiste en el uso de disección cadavérica, considerada una actividad de alto impacto moral, reflexivo, emocional y psicológico, vista incluso como una "actividad vital" (6), que provee además al estudiante con una vista tridimensional de las estructuras (7). La segunda, conocida como "modernista" (8), se enfoca en el uso de herramientas tecnológicas. Quienes se adhieren a esta corriente, aseguran que la disección cadavérica es una actividad costosa, dispendiosa y emocionalmente perturbadora promoviendo miedo y ansiedad entre quienes la practican (9). Tanto los cadáveres como la realidad virtual han demostrado ser herramientas motivadoras (10) y se ha determinado que una mezcla de las dos tendencias muestra mejores resultados que utilizar cualquiera de ellas por separado (11). Por este motivo, la disección cadavérica sigue siendo un elemento crucial a tener en cuenta, no sólo en la educación anatómica sino también ética del futuro profesional médico (12).

En 1977, con la introducción de la plastinación por el médico Gunther von Haggens y su exposición "Body Worlds", los ojos no sólo de los anatomistas, sino del mundo entero volvieron a centrarse en el cuerpo humano, causando tanto admiración (13) como molestia, incluso en la comunidad científica que consideró esta manera no convencional de exponer los cuerpos como anti-ética y ofensiva (14). Sin embargo, el anatomista debe enfrentarse hoy a los retos propuestos por esta exposición, ya que hay una necesidad imperativa por aplicar lo que le mostró al mundo, en la enseñanza e investigación en anatomía (14) dentro del ámbito médico.

Históricamente se observaron casos claramente especiales, durante el lapso en que estos cambios sucedieron, como el trabajo realizado por los anatomistas durante el III Reich, en el que se ilustra claramente que la teoría y la práctica de una ciencia es dependiente del sistema político existente (15), acarreando una transición de una práctica de disección ética a una utilización y disposición no ética de los cadáveres (16), al ser abandonados bajo la sigla N.N. del latín nomen necio (nombre desconocido) en los campos de concentración nazis (17). Estos casos censurables muestran también que el bien puede derivarse del mal y el uso continuo del "atlas" humano es el mejor tributo a quienes han fallecido, además, siempre ha sido y es aún, una herramienta valiosa, no sólo en la formación anatómica, sino ética e histórica del futuro profesional médico (18), siempre y cuando el contexto sea explicado y se haga explícito.

Actualmente, en pocos países las consideraciones éticas y legales para la donación de cuerpos para plastinación y estudio han llegado a un consenso, en el cual, el donante debe haber expresado en vida su decisión (19). En el caso colombiano, como en muchos otros países la investigación en anatomía se rige únicamente bajo la premisa del respeto al cadáver humano (20), tanto dentro como fuera del laboratorio de anatomía (21), principio inculcado desde temprano en la formación médica. Las leyes parecen regir mucho más firmemente el problema del diagnóstico, tratamiento y rehabilitación de la enfermedad de lo que deberían hacerlo en terrenos de tanta delicadeza ética como la educación anatómica actual (22), este es el caso de la normatividad acerca del consentimiento informado en anatomía patológica (23).

Únicamente se halla claramente estipulado en la literatura legislativa colombiana, que las instituciones científicas o educativas pueden disponer de cadáveres y órganos (provenientes de dichos cadáveres) no reclamados, para fines de docencia e investigación por medio del Instituto Nacional de Medicina Legal y Ciencias Forenses (INML) (24). Esta institución vela por 
el cumplimiento de las normas éticas y legales durante el proceso de entrega del espécimen.

Debería considerarse también el principio de autonomía, extrapolable del caso de donación de órganos para trasplante, ya que representa la voluntad altruista del difunto (25) de donar sus órganos para trasplante, o en este caso, para estudio. Esta normatividad no se encuentra aún definida, pero podría ser utilizada por medio de la figura del consentimiento informado en vida por parte del difunto o de sus familiares tras la muerte de la persona.

Aún en Colombia, el manejo ético dentro de los laboratorios de anatomía no está vinculado a normatividad alguna y por ende, el trato y manejo correcto de los cadáveres, órganos y especímenes extraídos de éstos, se encuentra ligado a las consideraciones del investigador, disector, profesor o estudiante que las maneje o la institución donde estas prácticas sean realizadas. El único mecanismo que lo asegura, y solo parcialmente, es la reglamentación en la práctica de autopsias médico-legales y viscerotomías, las cuales se han clasificado en sanitarias, docentes e investigativas (26), y deben ser realizadas sólo por personal avalado por el INML o en servicio social obligatorio (año rural).

Puntos tan importantes como el secreto profesional, que debe guardarse por respeto tanto al difunto como sus familiares (27), quedan al libre albedrío de quienes practiquen la disección cadavérica en los laboratorios universitarios, y sólo son inculcados por parte del profesor si éste decide hacerlo.

Debe entonces asegurarse que el proceso enseñanza y aprendizaje de la anatomía, ya sea utilizando cadáveres, sus partes, individuos vivos, o incluso materiales obtenidos de los mismos, transcurra en un marco de respeto y de cumplimiento de los principios éticos propios de las actividades formativas del futuro médico, acompañado del más alto valor científico (28).

\section{Referencias}

1. Jones G. Anatomical Investigations and their ethical dilemmas. Clinical Anatomy. 2007; 20: 338-343.

2. Barilan Y. Contemporary Art and the ethics of anatomy. Perspectives in Biology and Medicine. 2007; 50(1): 104-123.

3. Collins J. Modern approaches to teaching and learning anatomy. BMJ. 2008; 337: a 1310.

4. Dobson R. Anatomy teaching in United Kingdom is in crisis, new report says. BMJ. 2007; 334:12.
5. Cresswell A. Anatomy studies given an F. 2 Australian. Ene. 5 2007.

6. Weatherhall DJ. Science in the undergraduate curriculum during the 20th century. Medical Education. 2006; 1-37.

7. Vishnumaya G, Ramnarayan K. An appraisal of anatomy teaching and learning by undergraduate nursing students in a multiprofesional context: a study done at a Medical School in South India. Bratisl Lek Listy. 2009; 110 (8): 506-11.

8. Dobson R. Anatomy teaching in United Kingdom is in crisis, new report says. BMJ. 2007; 334:12.

9. M. Ashraf, Mckenzie J, et al. The Human Cadaver in the Age of Biomedical informatics. The Anatomical Record (New Anat.). 2002; 269: 20-32

10. Ávila R, et al. Ética y Docencia en Embriología Humana. Argentina: Facultad de Ciencias Médicas, Universidad Nacional de Córdoba; 2007.

11. Stanford W, Erkonen WE, Casselli M, Moran BD, Easley G, Carris RL, et al. Evaluation of a computer based programme for teaching cardiac anatomy. Invest. Radiol. 1994; 29: 248-252.

12. Rueda R, Martínez D, León L, Hernández J. Percepción de los estudiantes de la Facultad de Medicina de la Universidad de los Andes acerca de enseñanza y aprendizaje de Anatomía. [Proyecto de grado, en revisión para publicación]. Universidad de los Andes; 2010.

13. Rohrich R. Human Anatomy: The Common Denominator. American Society of Plastic Surgeons. 2007.

14. Jones G, Whitaker M. Engaging with Plastination and the Body Worlds Phenomenon: A Cultural and Intellectual Challenge for Anatomists. Clinical Anatomy. 2009; 22: 770-776.

15. Hildebrandt S. Anatomy in the Third Reich: An Outline, Part 3. The Science and Ethics of Anatomy in National Socialist Germany and Postwar Consequences. Clinical Anatomy. 2009; 22: 906-915.

16. Hildebrandt S; Capital punishment and Anatomy: History and Ethics of an ongoing Association; Clinical Anatomy. 2008; 21: 5-14.

17. Antía G. Cadáveres N.N. para la vida y la dignidad humana. El Colombiano. 2008.

18. Jones G. Anatomical Investigations and their ethical dilemmas. Clinical Anatomy. 2007; 20: 338-343.

19. Preuss D. Body Worlds: Looking back and looking ahead. Annals of Anatomy. 2008; 190: 23-32.

20. Resolución № 008430 de 1993. República de Colombia. Capítulo VI, Artículo 48.

21. Garment A, et al. Let the Dead Teach the living: The Rise of Body Bequeathal in 20th-Century America. Acad Med. 2007; 82: 100-1005.

22. Zambrano A. Aspectos Éticos del uso de la realidad virtual en la enseñanza de la Anatomía Humana. 2005; 44.

23. Veloz R. Consentimiento Informado en anatomía patológica como requerimiento ético para la calidad y la excelencia. Medisan. 2011; 15(1): 138-144.

24. Instituto de Medicina Legal y Ciencias Forenses. Resolución 485 del 11 de Octubre de 2002. Diario Oficial.

25. Guerra R. Donación de Órganos, Comprensión y significado. [Tesis para optar al título de Sociólogo].Universidad de Chile; 2005.

26. Presidencia de la República. Ministerio de Salud Pública. Decreto 786 de 1990. Diario Oficial No 39.300.

27. Boletín Oficial del Estado. Cualificación Profesional: Tanatopraxia. España; Núm. 41. Sec. I. 2011.

28. Wong T, Gutierrez A. Ética en la enseñanza de la anatomía humana: del cadáver a la realidad virtual. Edumecentro. 2009; 1(1). 
RuEDA R., HERNÁNDEZ J.

\title{
HUMAN ANATOMY: SCIENCE, ETHICS, DEVELOPMENT AND EDUCATION.
}

\author{
RuEDA Roberto* , HeRnÁNDEZ JUAN* \\ * Research Group for Education Anatomy, Faculty of Medicine, University of the Andes, Bogotá DC Colombia.
}

For centuries, the study of anatomy has remained as a neutral science from the ethics point of view, considering the good dissection and elimination of the specimens as its core. This image has been kept since the beginning of its study all the way to its development with the formaldehyde discovery, which allowed extending dissecting time, limited earlier by the natural putrefaction process, and until now, when polymers, special preparations and exhibitions are used in teaching and research.

The currently described crisis in the process of teachinglearning anatomy generated two educative currents widely used around the globe. One, still based on cadaveric dissection, considered as a vital tool. The second, using mainly the wide range of tools that the advancing technology has enabled to develop. However, these currents are not used excluding one or the other, and it is common that anatomical education uses a mixture of both to carry out the task of teaching, not only descriptive anatomical aspects but the noble labour of inculcating in the future medical doctors ethical values regarding the human body and medical practice.

There exist countless cases of non-ethical use of the human body for anatomical study. The resulting knowledge should not be demonized or censored, since even under erroneous political pressures, the study of anatomy and the use of the Human "Atlas" is a tribute to those who have died. It should rather be analyzed to become a valuable tool in teaching ethics and history to the future medical practitioner.

Nowadays, few countries have raised ethical and legal considerations under which must be governed the study of the human body. Colombia is one of the exceptions, as only a small amount of topics are regulated by the National Forensics and Legal Medicine Institute (INML, Spanish acronym for Instituto Nacional de Medicina Legal Ciencias Forenses) (7) within the wide range of activities the human body study carries out. Everything else is dictated almost exclusively on the basis of respect for the human body. Apparently, laws are more determined to deal with issues such as diagnosis, treatment and rehabilitation of diseases than they should be in an area as sensitive as cadaver's use in education.
Therefore, it is important that in an environment of freedom, both in and outside the amphitheatre, the future medical practitioner be trained by anatomists in an area of such sensitivity as medical ethics. Thus, a primary task for the researcher, teacher or dissector is to inculcate ethics and respect within the medical training activities as fundamental competencies in medical practice.

Considered for centuries as one of the mainstays of medical education and historically a cradle of ethical and religious dilemmas due to utilization of cadavers or anatomic 'Atlases' for its study, anatomy has traversed a long way under the image of an ethically neutral territory (1), all based on the way the human remains are preserved and presented (2), and dedicated to the descriptive study of macroscopic anatomy. A probably mistaken image that nowadays has been attempted to be discarded (1).

Since the discovery of formaldehyde in the XIX century, the study of anatomy could be prolonged during the time the specimen supported the dissection, and the restraint determined by the natural putrefaction process stopped being an issue. Ever since, the initiation of a race in search of novel and improved preservation techniques in favor of teaching, anatomy study and freedom to exert it was undertaken, often setting aside the ethical considerations which those techniques use could carry along.

According to these developments and presumably to the fact that anatomy teaching and learning are going through a crisis $(3,4,5)$, two trends for teaching anatomy were proposed. The first insists on use of cadaveric dissection, considered as an activity with a high moral, reflexive, emotional, and psychological impact, deemed even as a "vital activity" (6), which also provides the student with a tridimensional view of the structures (7). The second one, known as "Modernist" approach (8), is focused on the use of technological tools. Those who adhere to this current assure that cadaveric dissection is an expensive and emotionally disturbing activity promoting fear and anxiety among those who practice it (9). Both cadavers and virtual reality have been demonstrated to be motivating tools (10) and it has been determined that a mix of those two tendencies shows better results than using 
any of them separately (11). For this reason, cadaveric dissection has been a crucial element to be considered, not only in anatomic education but in the ethics of the future medical professional (12).

In 1977, with the introduction of plastination by Doctor Gunther von Haggens and his exhibition of "Body Worlds", not only the anatomists' eyes but those of the whole world went back to focus on the human body causing both admiration (13) and annoyance even among the scientific community who considered this nonconventional way of human body exposure as antiethical and offensive (14). However, today the anatomist should confront the challenges posed by that exposition since there is an imperative need to implement that what was exhibited to the world, both in anatomy teaching and research (14) within the medical environment.

Historically, clearly special cases were observed during the span when these changes took place, such as work performed by anatomists during the Third Reich era, in which is clearly illustrated that theory and practice of a science depends on the existent political system (15) entailing a transition from an ethical practice of dissection to an unethical use and disposal of cadavers (16) which were abandoned under the acronym N.N., from the Latin term "nomen necio" (unknown name), in the Nazi concentration camps (17). These censurable cases show that goodness can derive from evil as well, and continuous use of human "Atlas" is the best tribute to those who have died. Furthermore, it has always been, and still is, a valuable tool, not only in anatomic education but in ethical and historical formation of the future medical professional (18) provided that the context is explained and made explicit.

Presently, only in a few countries ethical and legal considerations for human bodies donation for plastination and study have reached a consensus in which the donor must have expressed his (her) decision while is alive (19). In the case of Colombia, likely in many other countries, anatomy research is ruled only under the premise of respect for the human cadaver (20), both inside and outside the anatomy laboratory (21), principle instilled early in the medical formation. Laws seem to be more determined to rule in diagnosis, treatment and rehabilitation of the disease than they should be in areas of such sensitivity as current anatomic education (22); this is the case with the regulations concerning the informed consent in anatomic pathology (23).
Colombian legislative literature only stipulates clearly that scientific or educational institutions can have at their disposition unclaimed cadavers and organs (originating from those cadavers) for teaching and research purposes through the National Forensics and Legal Medicine Institute (INML, Spanish acronym for 'Instituto Nacional de Medicina Legal y Ciencias Forenses') (24). This institution safeguards the fulfillment of the ethical and legal regulations during the process of the specimen delivery.

The principle of autonomy should also be considered, which is extrapolable from the case of organ donation for transplant, since it represents the humanitarian willingness of the dead person (25) to donate his (her) organs to be transplanted, or in this case, to be studied. This regulation is not yet defined but could be used through the figure of the informed consent given while the deceased person was alive or by relatives following his (her) death.

In Colombia, the ethical management within anatomy laboratories is not yet linked with any regulation and, therefore, the correct treatment and management of cadavers, organs and specimens drawn from them is associated with the judgments of the investigator, dissector, professor or student who manage them or the institution where these practices are being performed. The only mechanism that ensures it, and only partially, is the regulation on practices of medical-legal autopsies and viscerotomies, which have been classified into sanitary, educational and investigative (26), and should be carried out only by staff certified by INML or those who are completing their mandatory social service (1year rural service).

Topics of such importance as professional secret, which must be kept both for respect to the deceased and his (her) relatives (27), are left to the discretion of those who perform the cadaveric dissection in University laboratories, and only are inculcated by the professor if he (she) determines to do so.

This being the case, it should be ensured that the process of anatomy teaching and learning, whether it takes place using cadavers, their parts, alive individuals, or even materials obtained from them, takes place under a setting of respect and compliance with the ethical principles inherent to formative activities of the future doctors along with the upmost scientific values (28). 


\title{
ANATOMIA HUMANA: CIÊNCIA, ÉTICA, DESENVOLVIMENTO E EDUCAÇÃO
}

\author{
RUEDA ROBERTO* ${ }^{*}$ HERNÁNDEZ JUAN* \\ * Grupo de Pesquisa em Anatomia para a Educação, Faculdade de Medicina, Universidad de los Andes, \\ Bogotá D.C. Colômbia.
}

O estudo da anatomia permaneceu durante séculos como uma ciência neutra no âmbito ético, considerando a boa dissecação e disposição dos espécimes como sua base fundamental. Esta imagem vem se mantendo desde o inicio de seu estudo e desenvolvimento com o descobrimento do formaldeído, que permitiu prolongar o tempo de dissecação antes limitado pelo processo natural da putrefação, até a atualidade em que se utilizam polímeros, preparações especiais $e$ exposições não convencionais tanto em seu ensino como em sua pesquisa.

A atual crise que foi descrita no processo ensino-aprendizagem da anatomia gerou duas correntes educativas utilizadas amplamente ao redor do mundo, uma baseada ainda na dissecação cadavérica que é considerada uma atividade vital, a segunda utilizando principalmente o amplo leque de ferramentas que o avanço da tecnologia permitiu desenvolver. Porém, estas correntes não são utilizadas de maneira excludente, $e$ é comum observar que a educação anatômica utilize uma mistura destas duas práticas para realizar a tarefa de ensinar não só os aspectos anatômicos descritivos, mas também o nobre trabalho de inculcar no futuro profissional médico valores éticos relacionado ao corpo humano e a praxe médica.

Há inumeráveis casos de utilização antiética do corpo humano durante o tempo em que o estudo anatômico vem sendo praticado, cujos resultados não devem necessariamente ser satanizados nem censurados, já que inclusive sofrendo pressões políticas errôneas, o estudo da anatomia e a utilização do chamado "atlas" humano é um tributo aos que faleceram. Devem ser analisados, para que sejam uma ferramenta valiosa na formação ética, médica e histórica do futuro profissional médico.

$\mathrm{Na}$ atualidade, em poucos países foram propostas as considerações éticas e legais sob as quais deve ser regido o estudo do corpo humano. A Colômbia é uma das exceções, já que somente estão regulamentadas alguns apartes dentro do amplo leque de tarefas que acarreta o estudo do corpo humano pelo Instituto Nacional de Medicina Legal e Ciências Forenses (INML), todo o demais é regido quase que exclusivamente pela premissa do respeito ao cadáver humano. Parece que as leis regem mais firmemente problemas como o diagnóstico, tratamento e recuperação da doença do quê deveriam fazê-lo em um terreno de tanta delicadeza como o é a utilização de cadáveres na educação.

É importante então, que em um âmbito livre, tanto dentro como fora do anfiteatro, o futuro profissional médico seja treinado pelos anatomistas em um terreno tão delicado como o da ética médica. E é tarefa primordial do pesquisador, ou professor inculcar a ética $e$ o respeito dentro das atividades formativas médicas, como competências fundamentais na prática médica.

Considerada por séculos como uma das pedras angulares da educação médica e historicamente berço de múltiplos dilemas éticos e religiosos, devido à utilização de cadáveres ou atlas anatômicos para seu estudo, a anatomia percorreu um longo caminho com a imagem de ser um território eticamente neutro (1), baseando isto na forma em que se conservam e apresentam os restos humanos (2) e dedicada ao estudo descritivo da anatomia macroscópica. Uma imagem provavelmente errônea que hoje em dia esta tentando ser descartada (1).

A partir do descobrimento do formaldeído no século $\mathrm{XIX}$, o estudo da anatomia podia prolongar-se durante o tempo que o espécime suportasse a dissecação, e a limitante de tempo determinada pelo processo natural da putrefação deixou de ser um problema. Desde então, começou uma corrida em busca de novas e melhores técnicas de preservação em prol do ensino, o estudo da anatomia e a liberdade para exercê-la, deixando 
muitas vezes de lado as considerações éticas que a utilização dessas técnicas poderia trazer.

A partir desses desenvolvimentos o ensino $e$ a aprendizagem de anatomia entram em crise e $(3,4,5)$, apareceram duas tendências para ensinar anatomia. A primeira insiste no uso da dissecação cadavérica, considerada como uma atividade de alto impacto moral, reflexivo, emocional e psicológico, vista inclusive como uma "atividade vital" (6), que, além disso, fornece ao estudante uma visão tridimensional das estruturas (7). A segunda, conhecida como "Modernista" (8), enfoca-se no uso de ferramentas tecnológicas. Os que aderem a esta segunda corrente garantem que a dissecação cadavérica é uma atividade cara, dispendiosa e emocionalmente perturbadora promovendo medo e ansiedade entre os que a praticam (9). Tanto os cadáveres como a realidade virtual já demonstraram ser ferramentas motivadoras (10) e determinou-se que uma mistura das duas tendências mostra melhores resultados que utilizar qualquer uma delas separadamente (11). Por este motivo, a dissecação cadavérica continua sendo um elemento crucial a ser considerado, não somente na educação anatômica mas também na ética do futuro profissional médico (12).

Em 1977, com a introdução da plastinação pelo médico Gumther von Haggens e sua exposição "Body Worlds", os lhos não só dos anatomistas, mas sim do mundo inteiro voltaram a centrar-se no corpo humano, causando tanto admiração (13) como perturbação, inclusive na comunidade científica que considerou esta maneira não convencional de expor os corpos como antiética e ofensiva (14). Porém embargo, o anatomista deve enfrentar hoje em dia os desafios propostos por esta exposição, já que existe uma necessidade imperativa de aplicar o que foi mostrado ao mundo, no ensino $e$ pesquisa em anatomia (14) dentro do âmbito médico.

Historicamente foram observados casos claramente especiais, durante o lapso em que estas mudanças aconteceram, como o trabalho realizado pelos anatomistas durante o III Reich, no que se ilustra claramente que a teoría e a prática de uma ciência é dependente do sistema político existente (15), acarretando uma transição de uma prática de dissecação ética a uma utilização $e$ disposição não ética dos cadáveres (16), ao ser abandonados sob a sigla N.N. do latim "nomen necio" (nome desconhecido) nos campos de concentração nazistas (17). Estes casos censuráveis mostram também que o bem pode derivar da má utilização e o uso continuo do "atlas" humano é o melhor tributo aos que faleceram. Além disso, foi e ainda é uma ferramenta valiosa, não somente na formação anatômica, mas também ética $e$ histórica do futuro profissional médico (18), sempre que o contexto for explicado e se faça explicito.

Atualmente, em poucos países as considerações éticas e legais para a doação de corpos para a plastinação $e$ estudo chegaram a um consenso, no qual, o doador deve haver expressado em vida sua decisão (19). No caso colombiano, como em muitos outros países a pesquisa em anatomia é regida somente sob a premissa do respeito ao cadáver humano (20) tanto dentro como fora do laboratório de anatomia (21), principio inculcado desde cedo na formação médica. As leis parecem controlar muito mais firmemente o problema do diagnóstico, tratamento e recuperação da doença do que deveriam fazer em terrenos de tanta delicadeza ética como a educação anatômica atual (22), este é o caso da normatividade sobre o consentimento informado em anatomia patológica (23).

Somente está claramente estipulado na literatura legislativa colombiana, que as instituições científicas ou educativas podem dispor de cadáveres e órgãos (provenientes de tais cadáveres) não identificados, para fins de docência e pesquisa através do Instituto Nacional de Medicina Legal e Ciências Forenses (INML) (24). Esta instituição vela pelo cumprimento das normas éticas e legais durante o processo de entrega do espécime.

Deveria ser considerado também o principio de autonomia, extrapolável do caso de doação de órgãos para transplante, já que representa a vontade altruísta do defunto (25) de doar seus órgãos para transplante, ou neste caso, para estudo. Esta normatividade ainda não está definida, mas poderia ser utilizada através da figura do consentimento informado em vida pelo defunto ou seus parentes depois da morte da pessoa.

Na Colômbia, o tratamento ético dentro dos laboratórios de Anatomia não está vinculado a normatividade alguma e portanto, a manipulação e tratamento correto dos cadáveres, órgãos e espécimes extraídos dos mesmos, está ligado às considerações do pesquisados, professor ou estudante que os manipule ou à instituição onde as práticas forem feitas. $\mathrm{O}$ único mecanismo que garante, somente de forma parcial, é a regulamentação na prática de autopsias médico-legais e viscerotomias, que foram classificadas como sanitárias, docentes $e$ investigativas (26), e devem ser feitas somente por 
pessoal autorizado pelo INML ou que esteja fazendo serviço social obrigatório (ano rural).

Pontos tão importantes como o segredo profissional, que deve ser guardado tanto por respeito ao defunto quanto aos seus familiares (27), fiquem ao livre arbítrio dos que pratiquem a dissecação cadavérica nos laboratórios universitários, e só são inculcados por parte do professor se o mesmo decide fazê-lo.
Deve então garantir que o processo ensino e aprendizagem da anatomia, seja utilizando cadáveres, suas partes, indivíduos vivos, ou inclusive materiais obtidos dos mesmos, transcorra dentro de um ambiente de respeito e de cumprimento dos princípios éticos próprios das atividades formativas do futuro médico, acompanhado do mais alto valor científico (28). 